\title{
ARTIKELEN
}

\section{Coronacrisis en rechtspleging}

\author{
Frans van Dijk \& Eddy Bauw
}

\section{Inleiding}

De coronacrisis stelt de rechtspleging in alle getroffen landen voor grote organisatorische uitdagingen en fundamentele juridische vragen. In het hogere belang van de beteugeling van de verspreiding van het virus nemen overheden vergaande maatregelen, waarbij burgerrechten in het geding zijn. Aan burgers en bedrijven worden bij overtreding ingrijpende sancties opgelegd. Waar gaat het optreden van de overheid, in het belang van de gezondheid van haar burgers, te ver en welke eisen moeten daaraan worden gesteld? De maatregelen hebben ook grote financiële en sociale gevolgen. De economische effecten doen bedrijven ondanks omvangrijke financiële steun wankelen en een keur van conflicten over contracten ligt op de loer. Hoe moeten de risico's, die door niemand konden worden voorzien, worden verdeeld? Dit zijn evenzovele vragen die op enig moment aan de rechter zullen worden voorgelegd en het lijdt geen twijfel dat rechterlijke beslissingen in belangrijke mate de sociaaleconomische impact van de crisis zullen gaan bepalen. Tegelijkertijd is door gesloten gerechtsgebouwen en oplopende achterstanden in de eerste fase van de coronacrisis het beeld ontstaan van een tekortschietende rechtspleging. In deze bijdrage trachten wij, hoewel nog vroeg, een eerste beeld te geven van het functioneren van de rechtspleging in de coronacrisis. Centraal staan de vragen hoe de rechtspraak in de eerste fasen van de crisis heeft gefunctioneerd en welke rol de rechter zal kunnen gaan spelen in het verdere verloop van de crisis. Daarbij betrekken wij zowel het juridische als het sociaaleconomische perspectief. Het functioneren van de rechtspleging en de wijze waarop de rechter invulling geeft aan zijn rol heeft immers directe gevolgen voor de impact van de crisis op samenleving en economie.

In deze bijdrage moet het blijven het bij een eerste verkenning van de materie nu op het moment van schrijven harde data slechts beperkt voorhanden zijn en empirisch onderzoek (nog) niet goed mogelijk is. Het gaat hier dan ook om impressies en niet om een verslag van onderzoek. Wij volgen voor de structuur de chronologie. In de crisis en de directe gevolgen daarvan onderscheiden wij vier fasen, die zich voor een deel nog moeten voltrekken en die in de volgende vier paragrafen vanuit rechtsplegingsperspectief onder de loep worden genomen (par. 2 tot en met 5). Voor iedere fase worden het functioneren van de rechtspleging en de rol van de rechter beschouwd in relatie tot de mogelijke sociaaleconomische aspecten daarvan. Wij eindigen met enkele nog voorlopige en voorzichtige conclusies (par. 6). 


\section{De eerste (acute) fase}

Het beeld van de rechtspleging in de eerste acute fase van de pandemie kan moeilijk anders worden aangemerkt dan als zorgelijk. Op 16 maart 2020 werden de gerechtsgebouwen gesloten in navolging van het kabinetsbeleid. Het rechtspreken is niet volledig gestopt. De meest urgente zaken hebben doorgang gevonden. ${ }^{1}$ Daarbij ging het om voorgeleidingen en hechtenis van verdachten, faillissementen, zittingen rond verplichte zorg en/of zorgmachtigingen en urgente familiezaken zoals uithuisplaatsing en ondertoezichtstelling. ${ }^{2}$ De overige zaken werden aangehouden, voor zover deze niet schriftelijk konden worden afgedaan. Bij de zittingen die wel doorgingen werd gebruikgemaakt van videoconference of tele(fonisch) horen. Bij het zeer kleine aantal fysieke zittingen dat nog werd gehouden, was geen publiek, maar waren in beperkte mate wel de media aanwezig. Op 18 maart werden tijdelijke regelingen als aanvulling op de reguliere procesreglementen van de rechtbanken (familie en jeugd) en hoven (civiel) vastgesteld. ${ }^{3}$ Rechters en andere medewerkers werkten zo veel mogelijk thuis. De administratie werkte wel door op kantoor om schriftelijke behandeling gaande te houden. Na de verlenging van de maatregelen door het kabinet met ingang van 6 april is deze situatie gecontinueerd. Wel werd het aantal digitaal te behandelen zaken geleidelijk uitgebreid, maar zonder fysieke zittingen. ${ }^{4}$ De capaciteit voor online rechtspreken vanuit het eigen huis van rechters en later vanuit de gerechten werd uitgebreid. In een gezamenlijke verklaring van de Raad voor de rechtspraak, de rechtbanken, gerechtshoven en bijzondere colleges, de Hoge Raad en de Afdeling bestuursrechtspraak van de Raad van State van 23 april wordt gemeld dat 'achter de schermen (..) hard is gewerkt' en dat 'de gerechten worden aangepast aan de anderhalve meter afstand die voorlopig de norm is'. ${ }^{5}$ Op 1 mei wordt een 'Algemene regeling zaaksbehandeling Rechtspraak' bekendgemaakt, met regels over de aanwezigheid in de rechtszaal, de voorziening Veilig mailen en besloten zittingen. ${ }^{6}$

1 Een lijst van zeer urgente en urgente zaken werd op 16 maart openbaargemaakt.

2 Brief van de ministers van Justitie en Veiligheid en voor Rechtsbescherming en de staatssecretaris van Justitie en Veiligheid van 15 maart 2020, Kamerstukken II 2019/20, 25295, nr. 114.

3 Het overzicht van deze regelingen werd vervolgens op 25 maart en 1 mei (ten behoeve van de situatie na 11 mei) bijgewerkt, www.rechtspraak.nl/Voor-advocaten-en-juristen/Reglementenprocedures-en-formulieren/Paginas/Procesreglement.aspx.

4 De geleidelijke uitbreiding werd uitgelegd op www.rechtspraak.nl/Organisatie-en-contact/ Organisatie/Raad-voor-de-rechtspraak/Nieuws/Paginas/corona-Videozittingen-en-mailen-metde-rechtspraak.aspx.

5 www.rechtspraak.nl/Organisatie-en-contact/Organisatie/Raad-voor-de-rechtspraak/Nieuws/ Paginas/corina-rechtsprekende-instanties-in-gezamenlijke-verklaring-rechtspraak-gaatdoor.aspx?pk_campaign=rssfeed\&pk_medium=rssfeed\&pk_keyword=Nieuws-van-de-Raad-voorde-rechtspraak.

6 www.rechtspraak.nl/coronavirus-(COVID-19)/Paginas/COVID-19-Algemene-regelingzaaksbehandeling-Rechtspraak.aspx\#f052184a-b953-49e7-8547-ffd831445a3da32b6908c069-45db-a355-94c5665ca9a924. 
Als we inzoomen op de zaken die in de eerste fase zijn behandeld, dan zien wij dat tot 7 april twintig coronagerelateerde strafzaken zijn aangebracht. ${ }^{7}$ Hierbij ging het met name om de zogenoemde coronaspugers. Deze zaken werden snel afgehandeld, wat van belang was voor het signaal van een 'lik-op-stukbehandeling' naar de samenleving. Ook werden voorlopige voorzieningen behandeld in verband met de beperking van burgerlijke vrijheden, zoals het recht op demonstratie. $^{8}$ Vanaf 11 mei zijn fysieke zittingen met procespartijen weer beperkt mogelijk, als de aanwezigheid van partijen noodzakelijk is. Strafzaken, jeugd(straf)zaken en familiezaken hebben daarbij prioriteit, naar mededeling op www.rechtspraak.nl van die datum. De acute fase van de epidemie is dan ten einde, waarbij we 11 mei als markeringsmoment hanteren: de heropening van de basisscholen.

Wat betreft het aantal rechtszaken nam in deze periode niet alleen de afhandeling van zaken af, maar over de gehele linie ook de instroom van nieuwe zaken. ${ }^{9}$ Het aantal handelszaken liep sterk terug. Zelfs het aantal faillissementen daalde. Ook in het bestuursrecht was sprake van een daling. Het beeld voor bestuursrechtelijke en civiele zaken is dat er zeker tegen de achtergrond van de ingrijpende maatregelen van de overheid en van de dramatische effecten daarvan voor bedrijven verrassend weinig zaken zijn aangebracht. Een verklaring hiervoor kan zijn dat het overgrote deel van de burgers de beperkingen begreep en accepteerde of onder sociale druk daar geen werk van wilde maken. Daarnaast zijn door de ruime tegemoetkomingsregelingen van de overheid veel (potentiële) conflicten, bijvoorbeeld over de naleving van contracten, nog niet op scherp komen te staan. Met uitzondering van de nog steeds achterblijvende handelszaken en faillissementen is de instroom van de civiele en bestuursrechtelijke zaken inmiddels weer terug op het niveau van vorig jaar, maar de afdoening ervan loopt fors achter en de voorraden zijn sterk toegenomen. Hoewel de instroom van strafzaken een zeer sterke daling laat zien, is de afhandeling van al lopende zaken nog forser gedaald. Volgens politie en Openbaar Ministerie (OM) ligt een toenemend aantal zaken bij hen op afhandeling te wachten. ${ }^{10}$ Naar mededeling van de minister van Justitie en Veiligheid zijn in de periode van 17 maart 2020 tot 8 juni 2020 de achterstanden opgelopen met 14.000 misdrijfzaken en 22.300 overtredingszaken in eerste aanleg en 3.400 misdrijfzaken in hoger beroep. ${ }^{11}$ De roep om de afdoening buiten

7 Naar mededeling van de Raad voor de rechtspraak, www.rechtspraak.nl/Organisatie-en-contact/ Organisatie/Raad-voor-de-rechtspraak/Nieuws/Paginas/Afgelopen-weken-20-coronaspugers-enhoesters-voor-de-rechter.aspx. In totaal zijn bij het OM tot 10 mei 207 coronagerelateerde misdrijfzaken, waarin 164 personen zijn gedagvaard, en 18.200 overtredingen binnengekomen. Deze laatste hebben geresulteerd in 7.400 strafbeschikkingen, www.om.nl/actueel/nieuws/ 2020/05/22/cijfers-coronagerelateerde-misdrijven-en-overtredingen.

8 Zie o.m. Voorzieningenrechter Rb. Amsterdam 3 april 2020, ECLI:NL:RBAMS:2020:2126.

9 Datawarehouse Rechtspraak, Raad voor de rechtspraak, geraadpleegd tot 13 juni 2020.

10 www.om.nl/actueel/nieuws/2020/05/27/aanpak-wegwerken-voorraad-strafzaken.

11 Brief van 25 juni 2020 van de ministers van Veiligheid en Justitie en voor Rechtsbescherming aan de Tweede Kamer, Contouren aanpak achterstanden strafrechtketen, Kamerstukken II 2019/20, 29279 nr. 601. 
de rechter om uit te breiden werd al snel ingezet ${ }^{12}$ en is inmiddels al tot beleid verheven. ${ }^{13}$ Ook bij familie- en bestuursrechtelijke zaken zijn de voorraden toegenomen. Het gevolg is dat ook deze rechtszaken langer gaan duren dan in het oude normaal' het geval was. Het voorgaande komt erop neer, dat hoewel de instroom van zaken over de gehele linie gering was, een voorraad aan zaken zich elders heeft opgebouwd, respectievelijk bij het OM (in strafzaken) en bij burgers en bedrijven (overige zaken). Bij dit alles is het opmerkelijk te noemen dat bij handelszaken en faillissementen de instroom tot nu toe fors is afgenomen en de achterstanden niet zijn gegroeid. Het is echter aannemelijk dat de instroom ook hier geleidelijk zal toenemen. In paragraaf 5 gaan wij hier nader op in.

Geleidelijk nam in de eerste fase van de crisis de kritiek op de Rechtspraak toe. Deze kritiek was van tweeërlei aard. In de eerste plaats ging het om de sluiting van de gerechtsgebouwen. Fred Hammerstein begreep niet dat de rechtspraak kennelijk niet behoort tot de onmisbare onderdelen van onze maatschappij. ${ }^{14}$ Andere vitale onderdelen, waaronder uiteraard de ziekenhuizen, maar ook politie en brandweer, en de supermarkten werkten gewoon door. Volgens hem was de sluiting slecht voor het vertrouwen van burgers in de rechtspraak, moet de toegang tot de rechter juist in een tijd van uitzonderlijke maatregelen gewaarborgd blijven en ontstaan er nieuwe achterstanden bij de behandeling van zaken. Ook vanuit de (straf)advocatuur kwam veel kritiek. De reactie van de voorzitter van de presidentenvergadering, Robine de Lange, en de voorzitter van de Raad voor de rechtspraak, Henk Naves, had als strekking dat wel is doorgewerkt, veelal in schriftelijke procedures en dat de veiligheid van de bezoekers van de gerechtsgebouwen vooropstond. ${ }^{15}$

Kritische geluiden waren er (naast de kritiek op vreemdelingenzaken en jeugdzaken) vooral over de strafrechtspleging, zoals hiervoor al is aangestipt. In zijn column in De Telegraaf van 6 april 2020 verweet Van den Heuvel rechters het werk voor zich uit te schuiven en een gebrek aan creativiteit, durf en doorzettingsvermogen. De nieuwe korpschef van de politie, Henk van Essen, meende dat de gerechten te rigoureus zijn gesloten, met grote gevolgen voor de gehele strafrechtsketen en dat terwijl de politie gewoon heeft doorgewerkt. ${ }^{16}$ Deze kritiek wordt gestaafd door de hiervoor genoemde cijfers.

In de tweede plaats was er veel kritiek op de online en telefonische behandeling van zaken en met name op de onvoldoende bescherming van de rechten van verdachten daarbij. Vooral vanuit de advocatuur werd erop gewezen dat deze behandeling van zaken onvoldoende recht doet aan het beginsel van hoor en wederhoor. ${ }^{17}$ Principiële kritiek op het verloop van het strafproces kwam ook van

O.a. A-G Joep Simmelink in NRC Handelsblad: www.nrc.nl/nieuws/2020/05/14/de-achterstandis-alleen-buiten-de-strafrechter-om-op-te-lossen-a3999734.

13 Blijkens de in noot 11 genoemde brief aan de Tweede Kamer.

14 Hammerstein (2 april 2020), 'Overpeinzingen bij een crisis', www.ru.nl/cpo/verderdenken/ columns/overpeinzingen-crisis.

15 Reactie Henk Naves en Robine de Lange op 'Overpeinzingen bij een crisis' (9 april 2020), www.ru.nl/cpo/verderdenken/columns/overpeinzingen-crisis.

16 www.nrc.nl/nieuws/2020/04/30/40000-strafzaken-liggen-op-de-plank-a3998426.

17 Pijnappels 2020. 
het NJCM, ${ }^{18}$ dat van oordeel was dat de rechten van verdachten uit artikel 6 EVRM werden geschonden door geen aanwezigheid in persoon, geen aanwezigheid bij de gehele online zitting, geen contact met de advocaat ter zitting, maar soms wel aanwezigheid van het OM fysiek in de rechtszaal en niet de advocaat. Uit de slachtofferhoek was er ook veel kritiek: eerst mochten er in het geheel geen slachtoffers aanwezig zijn bij de zitting, daarna wel, maar dan zonder ondersteuning. Waar het gaat om de technisch kant, gaat het volgens de Rechtspraak in $80 \%$ van de zaken goed in de zin van de meest basale eis van een goed functionerende verbinding. Daarbij past de kanttekening dat it takes two to tango en dat ook advocaten en andere repeat players hun verbinding goed op orde moeten hebben. De bezwaren in strafzaken gelden ook voor andere zaken met kwetsbare justitiabelen, zoals familie- en jeugdzaken en vreemdelingenzaken.

Een voorlopige en voorzichtige conclusie met betrekking tot de eerste fase van de crisis is dat afgezien van de urgente zaken, de Rechtspraak te lang een (te) minimalistische opstelling heeft gehad. Voor het begin van de crisis valt deze opstelling te billijken. De karakteristieken van de pandemie waren immers onbekend en veiligheid stond voorop. Rechtspraak gaat gepaard met vele en wisselende bezoekers aan de gerechten en dat geeft kans op verspreiding van het virus en dat is voorkomen. Naarmate de crisis langer duurde en duidelijk werd dat deze nog veel langer ging duren, begon deze opstelling zich steeds minder te verhouden tot het belang van de toegang tot de rechter en de maatschappelijke functie van de rechtspraak. De strafrechtspleging is onnodig lang stilgevallen. Ook lijkt onvoldoende recht te zijn gedaan aan de processuele rechten van partijen en verdachten in de zaken die wel zijn doorgegaan. De gebruikte IT-middelen zijn nog (te) weinig geavanceerd om deze in alle opzichten te kunnen garanderen. Achter de schermen - dat wil zeggen: achter het bureau thuis - zijn wel de nodige zaken schriftelijk afgedaan.

Een risico van de zojuist beschreven 'erfenis' van de eerste fase van de coronacrisis is, in het domein van het strafrecht, dat de rol van de rechter en daarmee de rechtsbescherming verder wordt teruggedrongen ten faveure van het Openbaar Ministerie. Dat heeft al aangekondigd dat het, om de ontstane voorraad strafzaken te laten dalen, tijdelijk meer eenvoudige zaken zelf zal gaan afdoen. ${ }^{19} \mathrm{Bij}$ dat 'tijdelijk' kunnen al bij voorbaat vraagtekens worden geplaatst, zeker nu kostenbesparing en efficiency zwaarder zullen gaan wegen in de periode van economische recessie die ons nog te wachten staat. Voor de risico's van deze ontwikkeling volstaan wij hier met een verwijzing naar de keer op keer vastgestelde gebreken in

18 NJCM, Brief aan de minister van J\&V van 4 mei 2020 over zorgen over coronamaatregelen in de strafrechtspleging.

19 Zie www.om.nl/actueel/nieuws/2020/05/27/aanpak-wegwerken-voorraad-strafzaken. Zie ook de reactie hierop van de Nederlandse Vereniging voor Jonge Strafrechtadvocaten (NVJSA), www.nvjsa.nl/actueel/nieuws/reactie-nvjsa-op-berichtgeving-openbaar-ministerie-ten-aanzienvan-de-afdoening-middels-strafbeschikkingen. 
de rechtsbescherming bij de inzet van strafbeschikkingen die uit onderzoeken van de $\mathrm{P}-\mathrm{G}$ bij de Hoge Raad in de afgelopen jaren zijn gebleken. ${ }^{20}$

\section{De tweede (overgangs)fase}

In de tweede fase van transitie naar een normale(re) situatie worden de beperkingen geleidelijk (gedeeltelijk) versoepeld en kan ook de directe 'juridische afwikkeling', die in de eerste fase nog vrijwel geheel stillag, van de crisismaatregelen beginnen. De transitie is erop gericht de beperkingen gecontroleerd op te heffen en de economie weer meer te laten functioneren. Hoelang deze overgangsfase gaat duren, is onzeker. De duur van de overgang is afhankelijk van de gevolgen van de geleidelijke opheffing van lockdown-maatregelen, het gedrag van de bevolking, de effectiviteit van resterende maatregelen zoals het gebruik van mondkapjes in het openbaar vervoer en invloeden van over de landsgrenzen. De ervaringen in de zomermaanden laten zien dat het virus toch weer de kop kan opsteken en dat beperkende maatregelen (in bepaalde gebieden) heringevoerd worden. In september heeft het aantal besmettingen opnieuw een grote omvang bereikt. De mogelijkheid van een tweede golf in het najaar kan niet uitgesloten worden en is volgens sommigen zelf zeer waarschijnlijk. Het finale einde van de pandemie is er na het beschikbaar komen van een effectief vaccin en vaccinatie van de bevolking. Dat zal nog geruime tijd in beslag nemen en de nodige voeten in de aarde hebben.

Er zijn in deze overgangsfase drie bronnen van coronagerelateerde procedures te onderscheiden. In de eerste plaats zijn er de naweeën van de acute fase. $\mathrm{Nu}$ de druk er wat af is, krijgen andere belangen dan de bestrijding van de epidemie meer ruimte. Er is ook meer ruimte voor en behoefte aan discussie en kritiek. Beslissingen van de overheid worden nadrukkelijker en veelvuldiger aan de kaak gesteld en de juridische basis van de maatregelen wordt in twijfel getrokken. Het draagvlak onder de bevolking neemt af. De rechter heeft in deze fase een belangrijke rol te vervullen. Rechtspraak is naast een methode om geschillen te beslechten en strafbare feiten te berechten ook - in de zogenoemde public life conception van Luban - een middel voor het bewerkstelligen van conformiteit van de gedragingen van burgers aan de (sociale) normen. ${ }^{21}$ De rechter speelt een belangrijke rol in het maatschappelijk debat over rechten, belangen en normen. Hij kan een nuttige functie vervullen bij het dempen van maatschappelijke spanningen, bijvoorbeeld in de gevallen waarin burgers in verzet zijn gekomen tegen opgelegde coronaboetes. Enerzijds moet hij geloofwaardige bescherming van fundamentele rechten bieden en anderzijds het risico vermijden dat hij de effectiviteit van op deskundigeninzichten gebaseerde maatregelen en beslissingen ondergraaft. Verder is zijn taak te mediëren tussen de noodzakelijke handhaving van strenge maatregelen en 'het maatschappelijk sentiment', de burger voor wie de redelijk-

20 Het gaat om de rapporten 'Beschikt en gewogen' (2014), 'Wordt vervolgd: Beschikt en gewogen' (2017), 'Beproefd verzet' (2017) en 'Wordt vervolgd: Beproefd Verzet' (2019), te vinden op de website van de Hoge Raad.

21 Luban 1995. Voor Nederland: Loth \& Mak (2007). 
heid en eerlijkheid van die handhaving niet altijd meteen duidelijk is. Dat de scherpe kantjes er in de tweede fase ook wat meer van af kunnen, biedt de rechter ook meer ruimte om deze mediërende rol te vervullen. Daarbij komt dat nu de acute fase achter de rug is de weging die in het kader van de toetsing van de maatregelen aan de grondrechten moet worden gemaakt een andere uitkomst kan krijgen. Aan de juridische fundering ervan mogen hogere eisen worden gesteld. Die fundering zal ook vaker op de proef worden gesteld door burgers die ageren tegen de maatregelen en menen dat de beperkingen te ver gaan. Uit de uitspraken van rechters is overigens vooralsnog op te maken dat zij ook in deze fase overwegend terughoudend zijn om hierin mee te gaan. ${ }^{22}$

In de tweede plaats is er het transitiebeleid zelf. Dit heeft een gefaseerd karakter en dat betekent dat er winnaars en verliezers zijn. Het beleid heeft onvermijdelijk arbitraire kanten. Waarom binnenzwembaden wel en sportscholen niet tegelijk openstellen? Waarom pretparken wel en kermissen niet? Ook al steunt de overheid sectoren financieel, de keuzes hebben direct financiële gevolgen en het is onvermijdelijk dat het transitiebeleid tot procedures leidt, gedreven door economische belangen. Een voorbeeld hiervan was een dreigend kortgeding van een sportschool tegen de staat ter vervroeging van de heropening. Veel hangt in zo'n geval af van de opstelling van het kabinet dat zich responsief toonde, waardoor een rechterlijke uitspraak werd vermeden. Door nieuwe informatie uit onderzoek en voortschrijdend inzicht kan transitiebeleid steeds worden aangepast, zoals al gebeurd is ten aanzien van track and trace en mondkapjes. ${ }^{23}$ Dit kan onrust over de maatregelen en het nut en de noodzaak ervan voeden. Niet altijd zal door overleg en communicatie kunnen worden vermeden dat zich benadeeld voelende sectoren en bedrijven naar de rechter stappen. Er staat immers veel op het spel. Binnen de kaders van de juridische toetsing van de besluiten die hierbij vooropstaat, zal de rechter ook hier vooral een mediërende rol hebben te vervullen.

De derde en in potentie voornaamste bron van procedures is het tot stilstand komen van een groot deel van de economie. Dit heeft vroeger of later onvermijdelijk gevolgen voor het nakomen van contractuele verplichtingen. De centrale vraag zal hier worden hoe de risico's worden verdeeld en waar de schade uiteindelijk zal neerdalen. Vanwege het onvoorziene karakter van de crisis en de willekeur waarmee contractpartijen worden getroffen, veelal niet door eigen toedoen, wordt ervoor gepleit niet onverkort vast te houden aan contracten, maar de aandacht te richten op mitigering van gevolgen en de billijke verdeling van de schade. ${ }^{24}$ Ook hier is de mediërende rol van de rechter cruciaal voor het bereiken

22 Zie bijv. Rb. Amsterdam 3 april 2020, ECLI:NL:RBAMS:2020:2126 (Mondkapjes blijven in bepaalde delen van Amsterdam verplicht), Rb. Amsterdam 19 augustus 2020, ECLI:NL:RBAMS: 2020:4057 (demonstratie terecht verboden) en Rb. Midden-Nederland 9 september 2020, ECLI:NL:RBMNE:2020:3799 (geen inzage stukken RIVM).

23 Een recente metastudie concludeert dat (1) social distancing effectief maar duur is, in het bijzonder als daarmee laat begonnen wordt en (2) het zo snel mogelijk invoeren van handenwassen, mondkapjes, snel contact traceren en isoleren en beschermende uitrusting voor medische personeel de meest kosteneffectieve strategie is (Juneau e.a. 2020).

24 Zie o.m. Schelhaas \& Spanjaard (2020) en Principle 13 van de ELI Principles for the COVID-19 Crisis (ELI 2020). 
Tabel 1 Lengte van civiele procedures in handelsgeschillen in dagen, gemiddelde over 2016, 2017 en 2018

\begin{tabular}{lrr}
\hline Waarde van vorderingen in EUR & Eerste aanleg & Appel \\
\hline $0<c<1.000$ & 20 & 386 \\
$1.000 \leq c<10.000$ & 52 & 432 \\
$10.000 \leq c<100.000$ & 166 & 501 \\
$100.000 \leq c<1.000 .000$ & 346 & 592 \\
$1.000 .000 \leq c<5.000 .000$ & $5 \mid 3$ & 661 \\
$5.000 .000 \leq c<10.000 .000$ & 527 & 601 \\
$10.000 .000 \leq c<20.000 .000$ & 478 & 557 \\
$20.000 .000 \leq c<100.000 .000$ & 667 & 629 \\
$c \geq 100.000 .000$ & 731 & 764 \\
Zaken zonder financiële waarde & 168 & 408 \\
\hline
\end{tabular}

Bron: Costello e.a. (2020). Oorspronkelijke data: LDCR/Rvdr.

van uitkomsten die niet alleen voor contractspartijen, maar ook maatschappelijk acceptabel zijn.

In de handelszaken zijn de doorlooptijden lang, zoals blijkt uit figuur 1. In deze figuur wordt de lengte van procedures gegeven voor de waarde van vorderingen in handelszaken. Dit maakt duidelijk dat bij vorderingen met een groot financieel belang doorlooptijden snel oplopen. Benadrukt moet worden dat dit een uitkomst is van de interactie tussen rechters, advocaten en partijen (partijen zijn ook anno 2020 immers nog in hoge mate dominus litis) en niet alleen toegeschreven kan worden aan de tijd die de rechter aan de zaak besteedt.

Als de rechter niet veel sneller dan uit de tabel blijkt richting geeft aan de billijke verdeling van kosten, zal de coronacrisis onnodig grote schade toebrengen aan de economie. De uitdaging voor de rechtspraak is in deze fase gelegen in de beperking van doorlooptijden en het gebruikmaken van de mogelijkheden die de wetgeving biedt om zo snel mogelijk duidelijkheid te geven over de fundamentele juridische vragen die zich op tal van terreinen aandienen. Voor het eerste deel van de uitdaging dient de productiecapaciteit van de gerechten snel op het oude niveau gebracht te worden en liefst te worden vergroot. In het Verenigd Koninkrijk zijn hiervoor al vanaf begin augustus zogenoemde Nightingale courts ingericht. ${ }^{25}$ In Nederland zullen - afgezien van de al genoemde OM-afdoening - onder meer avondzittingen worden ingepland ${ }^{26}$ en gepensioneerde rechters worden ingezet. ${ }^{27}$ Hoe dan ook zal dit geen eenvoudige opgave zijn, vooral ook omdat de

25 www.gov.uk/guidance/courts-and-tribunals-additional-capacity-during-coronavirus-outbreaknightingale-courts.

26 www.rechtspraak.nl/Organisatie-en-contact/Organisatie/Rechtbanken/Rechtbank-MiddenNederland/Nieuws/Paginas/Rechtbank-Midden-Nederland-start-met-avondzittingen.aspx.

27 Mogelijk gemaakt door de Tweede Verzamelspoedwet COVID-19, Stb. 2020, 245. 
capaciteit om zaken te behandelen nog langere periode beperkt zal blijven. Dit is enerzijds het gevolg van de richtlijnen van het RIVM waar het fysieke zittingen betreft en anderzijds door de processuele bezwaren tegen digitale zittingen.

Voor alle zaken geldt dat het meer dan ooit van belang is dat optimaal gebruik wordt gemaakt van de mechanismen om zo snel mogelijk helderheid te geven over fundamentele rechtsvragen en daarbij duidelijke en voor partijen hanteerbare richtsnoeren te geven. Indien bijvoorbeeld waar het gaat om contractuele geschillen tot in hoogste instantie aan de hand van enkele zaken snel duidelijkheid wordt gegeven over de normen die gelden bij de verdeling van risico's die zijn ontstaan door het virus, stelt dit partijen in staat om hun onderlinge geschillen op een billijke manier op te lossen. Het Nederlandse contractenrecht is voldoende flexibel om te voorzien in uitkomsten die recht doen aan partijen en tegelijk onder coronaomstandigheden maatschappelijk en economisch aanvaardbaar zijn. Een voorbeeld hiervan is de suggestie om in het kader van een beroep op onvoorziene omstandigheden een heronderhandelingsplicht aan te nemen, waarbij als uitgangspunt wordt genomen dat het 'coronanadeel' 50/50 verdeeld moet worden. ${ }^{28}$ Los van de inhoud ervan - waarover wij de literatuur aanmoedigen om de discussie verder te verrijken - geven dergelijke richtsnoeren partijen bij een contract een kader waarmee zij zelf hun geschil kunnen oplossen en alleen als dat niet lukt de gang naar de rechter maken. De druk op de rechtspraak kan zo beheersbaar worden gehouden en veel (transactie)kosten inclusief de kosten van vertraging, die tot verdere economische schade voor partijen leiden, kunnen worden bespaard. De richtsnoeren kunnen via het stellen van prejudiciële vragen aan de Hoge Raad (art. 392 Wetboek van Burgerlijke Rechtsvordering, Rv) snel tot stand komen, waarbij tevens aan anderen dan partijen de gelegenheid wordt geboden om hun inbreng te leveren (art. $393 \mathrm{Rv}$ ). Gelet op vooral de economische consequenties die aan de vast te stellen richtsnoeren zijn verbonden, doet de Hoge Raad er goed aan deze mogelijkheid ruime bekendheid te geven en zelfs expliciet inbreng uit te lokken. ${ }^{29}$

Maar ook dit volstaat niet om de effecten van de coronacrisis op de rechtspleging en via de rechtspleging op samenleving en economie in de overgangsfase het hoofd te bieden. Naast het volume gaat kwaliteit een rol spelen. Er worden hogere eisen gesteld aan de rechtsbescherming dan in de acute fase. Het gaat hier in feite om normale eisen die aan een fair trial in een rechtsstaat moeten worden gesteld, maar onder de beperkingen die in de overgangsfase nog steeds gelden (denk vooral aan de ruimtelijke beperking als gevolg van de anderhalvemeter-norm) nog niet volledig kunnen worden gerealiseerd. Het is daarom van het grootste belang de slag naar op ruimere schaal digitaal procederen door te zetten en dit steeds beter in te regelen. Dit betekent ook dat er urgent een discussie nodig is over hoe fundamentele processuele rechten op andere (digitale) wijze dan fysiek (of een combinatie van beide) betekenisvol kunnen worden ingevuld. Die discussie moet

29 Tot op heden is de Hoge Raad hier nog terughoudend mee om gesprongen. Zie hierover nader Bauw (2019) op p. 32. 
ook internationaal worden gevoerd. Het gaat immers om internationale maatstaven en de ontwikkeling naar digitaal gaat nu overal met sprongen vooruit. ${ }^{30}$ Naast processuele rechten moet in dit verband ook worden gedacht aan het invulling geven aan de openbaarheid van rechtspraak.

$\mathrm{Bij}$ in ieder geval het gedeeltelijk voortzetten van digitale behandeling van zaken, zal voorts moeten worden onderzocht wat het effect is van digitale zittingen op beslissingen van rechters. Zo blijkt uit onderzoek in het Verenigd Koninkrijk, dat beslissingen over borgtocht online anders uitvallen dan bij fysieke zittingen. ${ }^{31}$ In digitale zittingen wordt $48 \%$ van de verzoeken tot borgtocht niet toegekend, terwijl dat in persoon $32 \%$ is. Een groot verschil, dat volgens het onderzoek samenhangt met technische problemen en gebrek aan kwaliteit. Risicomijdend gedrag van de rechter kan hieruit voortkomen. Een dergelijk effect kan ook in andere zaken optreden. Denk aan familiezaken of strafzaken. Een toename van het aantal fouten zou het gevolg kunnen zijn van slechtere communicatie en minder informatie uit lichaamstaal dan bij behandeling in persoon. Bepaalde typen bewijs krijgen wellicht voor de rechter minder bewijskracht dan zij zouden kunnen hebben. Het gaat dan in het bijzonder om verklaringen van verdachten en getuigen. Dat zou kunnen leiden tot meer vrijspraken in strafzaken. ${ }^{32}$ Om rechters in staat te stellen zichzelf hierop te corrigeren is nader onderzoek naar de hier bedoelde effecten nodig.

Voor het bredere veld van de rechtspleging kan verder nog aan andere problemen en beperkingen van de online behandeling van zaken worden gedacht. Gebruik makend van een recente policy brief van de OECD en de evaluatie van de Engelse Law Society, kan een overzicht worden gegeven van waar het hier om gaat en welke onderwerpen hier gezamenlijk door de verschillende partijen op het gebied van de rechtspleging zullen moeten worden opgepakt. ${ }^{33}$ Zo kunnen als problemen genoemd worden:

- De selectieve toegang tot online verbindingen, waarbij rechtzoekenden soms hun toevlucht moeten nemen tot computers in publieke ruimten.

- Het optreden van technische storingen in verbindingen en hoe daarmee om te gaan. Bepaald moet worden wanneer behandeling van de zaak moet worden gestaakt, bijvoorbeeld als een partij klaagt de zitting niet te kunnen volgen. Verder neemt door storingen de effectiviteit van pleidooien af en de kwaliteit van het horen van verdachten/partijen en getuigen.

- Een afstandsrelatie tussen cliënt en advocaat beperkt de communicatie en de effectiviteit van de inbreng, bijvoorbeeld van de verdediging in strafzaken. ${ }^{34}$ Ter zitting moet privécommunicatie tussen cliënt en advocaat mogelijk zijn.

- Omgang met anderstaligen en de inzet van vertalers.

- Psychologische effecten zoals het gevoel niet serieus te worden genomen en het mentaal afhaken, vooral bij lager opgeleiden, die het toch al moeilijk

30 Zie voor een overzicht https://remotecourts.org.

31 Bail Observation Project 2013.

32 Zie over rechterlijke fouten Sonnemans \& Van Dijk 2012.

33 OECD 2020 en Law Society 2020.

34 Zie ook Gibbs 2017 en Burton 2018. 
vinden om de communicatie met rechters en anderen te volgen, maar ook bij kinderen. ${ }^{35}$ Voor de rechter is moeilijker vast te stellen of rechtzoekenden begrijpen wat er in de zitting gebeurt en of zij niet afhaken. In lijn hiermee is het effect van de digitale zitting op de ervaren procedurele rechtvaardigheid en daarmee het vertrouwen in de rechter een belangrijk onderzoeksthema.

- Digitale verificatie van identiteit. Hoe kan vastgesteld worden dat het geen andere persoon is die spreekt?

- Openbaarheid van rechtspraak: openbaarheid is noodzakelijk voor controle van de rechtspraak, maar hoe kan dit op een open wijze gerealiseerd worden?

De omvang en complexiteit van zaken hoeft voor de online behandeling overigens niet bepalend te zijn. Zo zijn in het Verenigd Koninkrijk (London Commercial Court) en Nederland (Netherlands Commercial Court) grote handelsgeschillen succesvol behandeld. ${ }^{36}$ Professionele teams van advocaten in combinatie met gerechten die e-filing gebruiken maken dit mogelijk. De genoemde problemen lijken vooral kwetsbare justitiabelen, die altijd al moeite hadden de gang van zaken van rechtszaken te begrijpen, te raken. Daarnaast zouden ook doorgaans digitaal minder bedreven groepen, zoals ouderen, in het nadeel kunnen zijn. Als hier geen adequate oplossingen voor worden gevonden, lopen gerechten het risico de schijn van partijdigheid en mogelijk zelfs de indruk van klassenjustitie te wekken. Dit kan leiden tot afnemend vertrouwen in de Rechtspraak en andere instituties van de rechtsstaat, met name onder deze groepen. In geval van partijen die rechtsbijstand hebben, kan communicatie via een advocatenkantoor veel problemen voorkomen, maar dan moeten wel hoge eisen worden gesteld aan de kwaliteit van online verbindingen van advocaten. Ook zal de Rechtspraak hoge eisen moeten stellen aan de voorzieningen van gevangenissen, huizen van bewaring, asielcentra en zo meer, niet alleen met betrekking tot de verbindingen, maar ook de wijze waarop justitiabelen in beeld worden gebracht. Veel van de geschetste problemen zijn te ondervangen. Sterker nog, er is alle reden om ook na de pandemie de voordelen van online procedures te benutten. Dat vereist wel investeringen en onderzoek, vooral op de hierboven genoemde punten.

\section{Fase van economische teruggang}

De overgangsfase waarin de economische gevolgen van de pandemie en de gevolgen voor de rechtspleging zichtbaarder worden, zal geleidelijk met of zonder vaccin(s) overgaan in een periode van economische teruggang waarvan de duur en intensiteit zich nog niet goed laat inschatten. Het gaat immers om een type crisis waarmee nog geen ervaring is opgedaan en waarover gaandeweg kennis moet worden opgebouwd. Geheel anders dan bij de kredietcrisis is de economie bewust tot stilstand gebracht door de 'intelligente' lockdown. Hierbij is vooral de dienstensector (horeca, evenementen, toerisme, enz.) geraakt, terwijl de industrie

36 Zie Law Society (2020) en NCC, NCC News update nr. 9, 2020, www.rechtspraak.nl/English/ NCC/news/Pages/NCC-News-Updat-nr-9-Webinar-invitation-COVID19--.aspx. 
grotendeels (op een laag pitje) heeft doorgedraaid. Voor dit jaar is een grote verlaging van het BBP onvermijdelijk, maar voor 2021 is een aanzienlijk herstel mogelijk. In de meest recente prognose schat de Europese Commissie de teruggang dit jaar in Nederland op 6,8\% van het BBP en het herstel in 2021 op 4,6\% onder de aanname dat zich geen tweede coronagolf voordoet. ${ }^{37}$ Voor de gehele Europese Unie wordt een daling van het BBP met 8,3\% in 2020 en een plus van $5,8 \%$ in 2021. De werkloosheid in Nederland neemt volgens een eerdere prognose toe van 2,9\% tot circa $6 \%$ en herstelt zich daarna in 2021 licht tot 5,3\%. ${ }^{38}$ Ondanks de beperkte lockdown is het effect op de Nederlandse economie relatief groot vanwege de internationale afhankelijkheid. Door deze afhankelijkheid maar ook door de noodzakelijke aanpassing van economische activiteiten is nog maar de vraag of de voorspelling ten aanzien van het herstel uitkomt. Onderzoekers van de Rabobank schatten dat de anderhalvemeter-samenleving ertoe leidt dat activiteiten ter grootte van $10 \%$ van het BBP niet meer mogelijk zijn op de huidige manier, met name in de horeca, zorg en overige dienstverlening. ${ }^{39}$ Verschuivingen tussen sectoren en innovatie moeten een antwoord bieden, maar ook mag verwacht worden dat het anderhalvemeter-beleid aanhoudend en met steeds meer nadruk ter discussie wordt gesteld door degenen die schade lijden of uitvoering onmogelijk achten. Ook wordt inhoudelijk bepleit dat een 60 min-economie, waarbij rekening gehouden wordt met de sterk oplopende sterftekans bij hoge leeftijd en ouderen 'geïsoleerd' worden, een betere oplossing biedt dan de anderhalvemeter-economie. ${ }^{40}$

Ondanks het onzekere vooruitzicht van (snel) herstel, komen bedrijven, zzp'ers en anderen in liquiditeitsproblemen. Door overheidsbeleid worden net als bij de kredietcrisis de gevolgen voor hen gemitigeerd en daarmee de gevolgen voor de werkgelegenheid. Net als toen, worden hierdoor de negatieve effecten ook meer gespreid in de tijd, wat overigens het herstel kan afremmen. De steunpakketten helpen om faillissementen te voorkomen, maar dat zal lang niet altijd lukken, dan wel slechts tijdelijk soelaas bieden. De solvabiliteit van bedrijven komt immers ook in het geding doordat businessmodellen niet meer opgaan. Bestaande bedrijven zullen verdwijnen en nieuwe zullen ontstaan. Dit aanpassingsproces leidt vooral tot grote economische schade, als bedrijven failliet gaan die veel geïnvesteerd hebben in kennis en specifieke kapitaalgoederen. Vervanging is dan moeilijk en soms onmogelijk. Andere bedrijven, bijvoorbeeld in de horeca, kunnen relatief gemakkelijk vervangen worden door nieuwe bedrijven met nieuwe businessmodellen. In de huidige crisis is het laatste vooral aan de orde en zou de economische schade - in tegenstelling tot het leed voor de betrokkenen - beperkt kunnen blijven.

Wat betekent dit alles nu voor het beroep op de rechter in deze fase? Tot op heden is het aantal handelszaken en faillissementen sterk gedaald. Het is echter niet aannemelijk dat dit na het afbouwen van de ruime overheidssteun zo blijft.

40 Fransman e.a. 2020, gebaseerd op Acemoglu e.a 2020. 
Kijken we naar eerdere crises, dan is waarschijnlijk dat het beroep op de rechter toeneemt. Dat was zo bij de grote depressie van voor de Tweede Wereldoorlog en recentelijk ook bij de kredietcrisis. ${ }^{41}$ Tijdens de kredietcrisis zagen we het volgende beeld. Vanaf de driejaarsperiode $2003 / 4 / 5$ is het aantal civiele handelszaken eerst gestegen met ruim $40 \%$ in 2009/10/11 en daarna in 2015/16/17 gedaald tot onder het beginniveau. De totale waarde van de claims nam toe met $105 \%$ om daarna te dalen tot $33 \%$ boven het niveau van 2003/4/5.

Hierboven wezen we er al op dat veel bedrijven hun contractuele verplichtingen niet kunnen nakomen en dat dit zal leiden tot meer handelszaken. Naar verwachting zullen deze geschillen eerst in de plaats treden van de handelszaken die bij een groeiende economie horen. In de advocatuur is deze ontwikkeling reeds zichtbaar in een verschuiving van het werk van bijvoorbeeld fusies en overnames naar crisisgerelateerd werk in het arbeidsrecht en faillissementsrecht, waarbij de verwachting is dat de omzet dit jaar zelfs toeneemt. ${ }^{42}$ Deze zaken bereiken pas met een vertraging de rechtspraak. Op iets langere termijn lijkt daarom een forse toename van het aantal en de waarde van civiele handelszaken onvermijdelijk, zeker als covid wereldwijd nog diepere sporen gaat trekken. Het is aannemelijk dat ook de toename van faillissementsaanvragen geleidelijk zal verlopen. Zelfs als de schade van de crisis macro-economisch mee zou vallen, zal door de impact van covid op de businessmodellen van bedrijven het aantal faillissementen stijgen. Uit eerdere crises weten we ook dat hogere werkloosheid leidt tot meer criminaliteit en meer strafzaken. ${ }^{43}$

Door de door ons verwachte toename van het aantal zaken gaat het (veel) langer duren om deze af te handelen. Deze vertraging in de afhandeling van zaken draagt bij aan de economische en maatschappelijke schade van de pandemie. Burgers en bedrijven verkeren langer in onzekerheid over de uitkomst van een geschil en worden daarmee gedwongen tot 'inactiviteit'. ${ }^{44}$ Zonder rechterlijke beslissing blijft bijvoorbeeld onduidelijkheid bestaan over de nakoming van contracten en dat kan investeringsbeslissingen belemmeren. Ter indicatie en nog afgezien van faillissementen als gevolg van het niet tijdig oplossen van contractuele problemen, kunnen de maatschappelijke kosten hiervan geraamd worden. Een onlangs afgeronde pilot study van het Montaigne Centrum voor Rechtsstaat en Rechtspleging van de Universiteit Utrecht en het European Network for Councils for the Judiciary (ENCJ) vindt dat voor handelszaken met een financieel belang van meer dan $€ 1$ miljoen de maatschappelijke kosten van het verschil tussen de pre-coronapraktijk in Nederland en de gevonden Europese best practice (namelijk die in Noorwegen), in de orde liggen van jaarlijks $€ 425$ miljoen. ${ }^{45}$ Dit betreft een conservatieve raming voor één categorie van zaken, maar wel een belangrijke. De berekeningsmethode die hieraan ten grondslag ligt, kan gebruikt worden om een indicatie te geven van de maatschappelijke kosten van meer procedures en de kos-

41 Bauw e.a. 2009 en Van Dijk 2019.

42 Laane 2020. Voor 2021 wordt overigens een daling van de omzet van de advocatuur met $1 \%$ verwacht.

43 Molenaar e.a. 2018.

44 Van Dijk 2014 en Bauw 2011.

45 Costello e.a. 2020. 
Tabel 2 Toename van maatschappelijke kosten per jaar van meer handelszaken en langere tijdsduur

\begin{tabular}{lrrrr}
\hline & \multicolumn{3}{c}{ 25\% extra volume } & 25\% extra tijdsduur \\
\hline $\begin{array}{l}\text { Waarde van vorderingen in } \\
\text { handelszaken, ingeleid bij dag- } \\
\text { vaarding in EUR }\end{array}$ & Rechtbank & Hoger beroep & Rechtbank & Hoger beroep \\
$0<c<1.000$ & & & & \\
$1.000 \leq c<10.000$ & 2.051 .828 & 33.559 & 47.601 & 283 \\
$10.000 \leq c<100.000$ & 13.338 .049 & $819.89 \mid$ & 463.123 & 57.395 \\
$100.000 \leq c<1.000 .000$ & 28.181 .600 & 2.822 .225 & 2.677 .625 & 933.042 \\
$1.000 .000 \leq c<5.000 .000$ & 50.626 .743 & 12.870 .980 & 9.489 .678 & 4.263 .725 \\
$5.000 .000 \leq c<10.000 .000$ & 42.768 .625 & 12.011 .473 & 13.482 .656 & 6.622 .675 \\
$10.000 .000 \leq c<20.000 .000$ & 11.471 .709 & 3.105 .017 & 7.670 .886 & 2.713 .563 \\
$20.000 .000 \leq c<100.000 .000$ & 6.815 .550 & $3.046 .54 \mid$ & 5.700 .687 & 3.115 .467 \\
$c \geq 100.000 .000$ & 18.148 .624 & 7.081 .677 & 20.073 .280 & 8.238 .555 \\
Totale waarde vorderin- & $\mathbf{2 6 5 . 0 3 9 . 6 3 7 . 1 8 4}$ & 7.675 .338 & 113.446 .480 & 9.495 .214 \\
gen & & 49.466 .702 & 173.052 .017 & $\mathbf{3 5 . 4 3 9 . 9 1 9}$ \\
\hline
\end{tabular}

Toelichting: de raming bestaat uit drie onderdelen: (I) de kosten die voortvloeien uit de tijd die gemoeid is met rechtszaken, berekend op basis van de totale waarde van de vorderingen bij aanbrengen en een discontovoet van 4\%, (2) de kosten van de behandeling van de zaken door het gerecht en (3) de advocaatkosten. Zie verder Costello 2020.

ten van een nog langere duur van procedures als gevolg van de coronacrisis. Om hiervan een indicatie te geven, worden in figuur 2 ramingen van de maatschappelijke kosten van 25\% meer handelszaken en $25 \%$ langere procedures gegeven. Hierbij gaat het alleen om dagvaardingszaken. Verzoekschriftzaken, inclusief faillissementen, zijn buiten beschouwing gelaten. De extra maatschappelijke kosten liggen dan toch al in de orde van $€ 0,5$ miljard per jaar. Een dergelijke uitkomst moet en kan vermeden worden. De contouren hiervan zijn in het voorgaande geschetst.

\section{Langetermijneffecten}

Tot slot nog aandacht voor de verwachtingen voor de effecten van de pandemie voor de rechtspleging op de langere termijn. In de eerste plaats mag verwacht worden dat geprocedeerd zal worden over de schuldvraag en over tekortkomingen in de aanpak van de crisis. Al in de overgangsfase worden rechtszaken voorbereid of geïnitieerd. In Italië is het Openbaar Ministerie een breed strafrechtelijk onderzoek begonnen naar het optreden van lokale autoriteiten in de crisis, waarbij in eerste instantie wordt gekeken naar Bergamo en Genua. In Oostenrijk is een strafklacht ingediend tegen de lokale bestuurders van het skioord Ischgl. Hier werden honderden mensen besmet, die het virus naar andere landen brachten. De Oostenrijkse consumentenorganisatie VSV bereidt een collectieve schadeclaim 
voor tegen diezelfde autoriteiten. In Frankrijk hebben zeshonderd artsen zich verzameld in het 'C19 Collectief' en hebben verzocht om een strafrechtelijk onderzoek te starten naar de premier en de minister van volksgezondheid, die verantwoordelijk zouden zijn voor het onvoldoende voorbereid zijn op de pandemie. ${ }^{46}$ Het behoeft hier geen betoog dat in de Verenigde Staten de komende jaren de coronacrisis een Lawyers Paradise zal zijn. ${ }^{47}$ In Nederland zullen vragen worden gesteld over de hoogte van het sterftecijfer ten opzichte van andere landen, over de verzorgingstehuizen die in de eerste fase onvoldoende waren beschermd en over onduidelijkheden in het beleid. Er is tot 1 juni weinig getest, terwijl dat wel de mondiale standaard was. Hoe stond het met het niveau van voorbereiding? Men zou kunnen betogen dat uit hoofde van artikel 2 EVRM de overheid gehouden is tot een grondig onderzoek naar de gang van zaken. Uiteraard gaat het hier voor een belangrijk deel om vragen die vooral en in de Nederlandse verhoudingen in eerste instantie door de politiek gesteld, onderzocht en beantwoord moeten worden, maar een spin-off daarvan bij de rechter mag worden verwacht als gedupeerden hier geen genoegen mee nemen.

Daarnaast zal de vraag worden gesteld naar de preventie van dergelijke crises in de toekomst. Het lijkt naïef om de pandemie als een eenmalige freak event te beschouwen en betere voorbereidingen zijn vereist. Met de kennis en ervaring die nu zijn opgedaan, zou het voor de overheid duidelijker dan ooit moeten zijn welke verplichting zij hier heeft ten opzichte van haar burgers. Met de mogelijkheid van een beroep op de positieve verplichtingen voortvloeiend uit (in ieder geval) artikel 2 EVRM bij de rechter kunnen de inspanningen van de overheid kritisch worden gevolgd. De keerzijde van de forse inzet op preventie is echter eveneens duidelijk. Generieke monitoring van de gezondheid van de burger lijkt onvermijdelijk met koppeling aan bewegingsvrijheid, zoals mogen reizen, en het is niet eenvoudig om dit in evenwicht te brengen met burgerlijke vrijheden. Ook de koppeling aan persoonlijke karakteristieken zoals leeftijd (60min-economie!) roept tal van vragen op.

\section{Conclusies}

Hoewel het nog te vroeg is om het functioneren van de rechtspleging echt te evalueren en voorspellingen te doen over de komende periode, staat vast dat de rechter en de rechtspleging in bredere zin zich mogen opmaken voor drukke tijden, maar vooral ook voor de behandeling van tal van principiële kwesties. Aan de organisatorische kant is het een enorme uitdaging om de productiecapaciteit uit te breiden, de achterstanden weg te werken en te vermijden dat procedures nog langer gaan duren. Wij hebben laten zien dat als de Rechtspraak hier niet in slaagt, dit consequenties heeft voor het rechtsstatelijk vertrouwen en het herstel van de economie. Ook zal, vooral in het strafrecht, verder aan het domein van de

46 Zie 'Here comes the first wave of coronavirus lawsuits', www.wired.co.uk/article/coronaviruslawsuits.

47 Zie o.a. Bocott, O. \& A. Giuffrida, 'From an Italian hotel to a US state, coronavirus 'lawfare' takes off, Guardian 23 april 2020. 
rechter worden geknaagd ten koste van de rechtsbescherming. Op andere rechtsgebieden zullen de ambities om te komen tot 'maatschappelijk effectieve rechtspraak' ${ }^{48}$ onder druk komen te staan van de drang om 'productie te draaien'. Verschraling en marginalisering liggen op de loer.

Een andere minstens zo forse uitdaging is gelegen in het gelijktijdig versterken van de (digitale) weerbaarheid van de rechtspraak en voor het functioneren van voor de rechtsstaat vitale infrastructuur. De ervaringen in de eerste acute fase van de crisis hebben de kwetsbaarheid van de organisatie en de noodzaak van verbetering aan het licht gebracht. Er is in korte tijd veel geleerd en georganiseerd - en dit verdient veel respect - maar het getoonde is nog verre van voldoende en met urgentie (denk aan een mogelijke tweede golf van besmettingen) dient hier actie op te worden ondernomen. Niet moet hier uit het oog worden verloren dat de Rechtspraak onderdeel is van veel ketens, waarvan de strafrechtketen er een is, en dat deze ketens vastlopen als de gerechten niet functioneren. In de overgangsfase waarin wij op dit moment nog verkeren, moet de Rechtspraak assertief zijn in wat digitaal wel en niet verantwoord is. Dat vereist deskundigheid op dit vlak. Onderzoek zal hierbij kunnen ondersteunen.

Intussen zullen de rechters te midden van deze organisatorische uitdagingen zich onverstoorbaar moeten concentreren op de belangwekkende rechtsvragen die op hun bord komen te liggen. Vragen met grote maatschappelijke en economische gevolgen. Snelle beantwoording van deze vragen in de vorm van duidelijke richtsnoeren via prejudiciële procedures met inbreng van belanghebbende partijen en organisaties is nodig om de rechterlijke macht optimaal zijn rol te laten vervullen om Nederland zo goed mogelijk door de coronacrisis heen te helpen.

\section{Referenties}

Acemoglu, D., V. Chernozhukov, I. Wening \& M.D. Whinston, Optimal targeted lockdowns in a multi-group SIR model, NBER working paper 27102, 2020.

Bail observation project, Still a travesty: justice in immigration bail hearings: Second report from the bail observation project, p. 5, https://bailobs.org, 2013.

Bauw, E., 'Inspraak in de civiele rechtspraak', in: Nederlandse Vereniging voor Procesrecht, Inspraak in de rechtspraak: de rol van derden in de procedure, 2019, p. 25-35.

Bauw, E., Rechtspraak in tijden van crisis (oratie UvA), Amsterdam: Vossius Pers 2011.

Bauw, E., F. van Dijk \& F. van Tulder, 'Recessie en rechtspraak', ESB 2009-94, p. 468-471.

Burton, M., 'Justice on the line? A comparison of telephone and face-to-face advice in social welfare legal aid', Journal of Social Welfare and Family Law 2018-40, p. 195-215.

Costello, C., F. van Dijk, S. Giorgi, L. Griskevic, F.E. Holm, D. Leitao Requena, W. Storhaug Larssen, S. Sicking \& N. Meilutis, 'Economic value of the judiciary; A pilot study for five countries on volume, value and duration of large commercial cases', Montaigne Center/Utrecht University and ENCJ 2020, www.encj.eu/node/563, 2020.

Drion, C., 'Corona en onvoorziene omstandigheden', NJB 2020, p. 1251.

Dijk, F. van, Conflicten in economische ketens, Den Haag: Boom juridisch 2019.

Dijk, F. van, Improved performance of the Netherlands Judiciary: assessment of the gains for societ, International Journal for Court Administration, 2014-(6), p. 1-17. 
Eagly, I.V., 'Remote adjudication in immigration', Northwestern University Law Review 2015-109(4), p. 933-1020.

ELI, ELI Principles for the COVID-19 Crisis, www.europeanlawinstitute.eu/news-events/ upcoming-events/events-sync/news/eli-publishes-principles-for-the-covid-19-crisis/? tx_news_pi1\%5Bcontroller\%5D=News\&tx_news_pi1\%5Baction

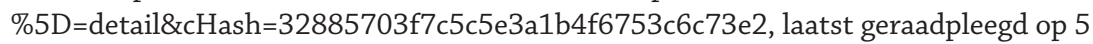
juni 2020.

European Commission, European economic forecast, Institutional paper 125, 2020a.

European Commission, European economic forecast, Institutional paper 132, $2020 \mathrm{~b}$.

Fransman, R., X. Koolman, E-J Vlieger \& A. Sipkema, 'De 60min-economie leidt tot betere resultaten dan de anderhalvemetereconomie', ESB 2020, https://esb.nu.

Gibbs, P., Defendants on video - conveyor belt justice or a revolution in access?, Justice Transform 2017, www.barrowcadbury.org.uk/content/uploads/2017/10/TJ.

Groenewegen, J. \& S. Hardeman, 'De anderhalvemetereconomie van Nederland gemeten', www.mejudice.nl, 2020.

Juneau, C.E., T. Pueyo, M. Bell, G. Gee \& L. Potvin, 'Evidence based, cost-effective interventions to suppress the COVID-19 pandemic: a rapid systematic review', medRxiv preprint, 2020, doi: 10.1101/2020.04.20.20054726.

Kitzinger, C., 'Remote justice: a family perspective', Transparency Project UK, www.transparencyproject.org.uk/remote-justice-a-family-perspective, 2020.

Laane, I., Zakelijke dienstverlening is nog niet klaar met corona; Sectorprognose Zakelijke dienstverlening, september 2020, ABN-AMRO 2020.

Law Society, The Law Society's response to the Civil Justice Council's rapid consultation on the impact of COVID-19 measures on the civil justice system.

Loth, M.A. \& E. Mak, 'Het rechterlijk domein in beeld. Cijfers, trends en perspectieven', in: M. van Berckel \& Y. Roijers (red.), Rechtspraak 2015, Den Haag: Sdu Uitgevers 2007, p. 47-87.

Luban, D., 'Settlements and the erosion of the public realm', The Georgetown Law Journal 1995, p. 2619-2662.

Molenaar, D., P. Smit, R. Decae, F. van Tulder \& B. Diephuis, Capaciteitsbehoefte Justitiële ketens $t / m$ 2023, WODC Cahier 2018-10.

OECD, Impact of COVID-19 on access to justice Policy Brief, 2020.

Pijnappels, F., 'Met duur van crisis stijgen de zorgen', www.advocatenblad.nl/2020/04/22/ zorgen-nemen-toe-met-duur-van-de-crisis, 2020.

Schelhaas, H. \& J. Spanjaard, 'Contract en coronacrisis', NJB 2020(14), p. 956-969.

Sonnemans, J. \& F. van Dij, 'Errors in judical decisions: experimental results', Journal of law, economics and organization 2012-28(4), p. 687-716.

Terry, M., S. Johnson \& P. Thompson, 'Virtual Court Pilot: outcome evaluation', UK Ministry of Justice Research Series, 2010-21(10).

Tjittes, R.J., 'Commerciële contracten en corona: uitgangspunt 50/50 verdeling nadeel', www.barentskrans.nl/nieuws/commerciele-contracten-en-coronauitgangspunt-50-50-verdeling-nadeel, 2020. 